\title{
PERANCANGAN SISTEM INFORMASI AKUNTANSI PENGGAJIAN (MANUAL)
}

\section{DESIGN OF ACCOUNTING INFORMATION SYSTEMS OF SALES (MANUAL)}

\author{
Umi Kulsum ${ }^{1}$, Moh. Halim², Nina Martiana ${ }^{3}$ \\ Universitas Muhammadiyah Jember ${ }^{1,2,3}$ \\ umiks0996@gmail.com ${ }^{1}$
}

\begin{abstract}
ASBTRACT
Accounting information system is made to facilitate the execution of remuneration to be more efficient and effective, because this system is very influential for companies to meet the needs of external parties and management. This study was conducted to determine the payroll accounting applied by $C V$. Serampang Jaya. This type of research is a type of qualitative descriptive research with a case study approach that describes and explains a problem syteatically and factualy so that by gathering information relating to the object of resarch. The data sources used are primary data and secondary data. The data colection techniquesuse used are observation, interview, and docuentation. The technique used in analyzing is to develop and explain how the payroll accounting system applied by $C V$. Serampang Jaya. The use the design of employee payroll accounting information system on $C V$. Serampang Jaya is in acorndance with existing theories. The results showed that CV. Serampang Jaya has impleented a payroll accounting system but still needs improvements to be effective in the payroll accounting record process at CV. Serampang Jaya.
\end{abstract}

Keywords: Payroll, Accounting, Information System

\begin{abstract}
ASBTRAK
sistem informasi akuntansi dibuat untuk memudahkan pengerjaan penggajuan agar lebih efisien dan efektif, disebabkan sistem ini sangat berpengaruh besar bagi perusahan memenuhi kebutuhan pihak eksternal dan pihak menajemen. Penelitian ini dilakukan untuk mengetahui akuntansi penggajian yang diterapkan oleh CV. Serampang Jaya. Jenis penelitian ini adalah jenis penelitian deskriptif kualitatif dengan pendekatan studi kasus yang menggambarkan dan menjelaskan suatu masalah secara fakta dan faktual sehingga dengan mengumpulkan informasi yang berkaitan dengan objek penelitian. Sumber data yang digunakan adalah data primer dan data sekunder. Teknik pengumpulan data yang digunakan adalah observasi, wawancara, dan dokumentasi. Teknik yang digunakan dalam menganalisis adalah mengembangkan dan menjelaskan bagaimana sistem akuntansi penggajian yang diterapkan oleh CV. Serampang Jaya. Penggunaan desain sistem informasi akuntansi penggajian karyawan pada CV. Serampang Jaya memiliki kaitan dengan teori-teori yang ada. Hasil penelitian menunjukkan bahwa CV. Serampang Jaya telah menerapkan sistem akuntansi penggajian tetapi masih perlu perbaikan agar efektif dalam proses pencatatan akuntansi penggajian di CV. Serampang Jaya.
\end{abstract}

Kata Kunci: Penggajian, Akuntansi, Sistem Informasi 


\section{PENDAHULUAN}

Dengan adanya persaingan secara global, pada saat ini terdapat beberapa perusahaan-perusahaan dibeberapa bidang terdapat persaingan yang sangat ketat diantaranya ialah pada bidang SDM, sumber daya modal secara efisien dann efektif. Sumber daya manusia sangat berpengaruh dalam sebuah perusahaan. Mereka bekerja untuk mencapai tujuan perusahaan, sebagai imbalannya perusahaan. perusahaan harus memberi upah yang berbeda sesuai tugas yang diemban pada suatu perusahaan. Hal ini dilakukan guna untuk memotivasi para pegawai agar semakin giat dalam bekerja.

Soemarso (2004) menyatakan bahwa gaji merupakan upah dari atasan yang diberikan kepada bawahannya karena telah melakukan tugas yang diperintahkan yang diberikan setiap 30 hari sekali. Upah yang diberikan oleh pimpinan perusahaan sesuai dengan tugas yang diemban di tempat kerjanya.

Sistem penggajian dalam sebuah perusahaan juga sangat berperan penting bagi suatu perusahaan dan bagi karyawan. Mulyadi (2000) mengatakan bahwa (SIA) sistem informasi akuntasi penggajajian ini dipakai guna sebagai pencatatan gaji karyawan, pembayaran serta gaji bagi karyawan yang bulanan ataupun harian jam hari ataupun berdasar jumlah produk. Menurut Romney dan Steinbart menyatakan bahwa terdapat kolusi yang sering muncul pada perusahaan yaitu mengenia gaji perjam, bulanan serta mingguan disebabkan kurangnya informasi yang akurat. dalam sebuah perusahaan sebuah catatan yang tidak lengkap mengakibatkan seorang menejer akan sulit dalam memberikan keputusan serta bisa mengakibatkan peusahaan juga merasakan sebuah dampak negatif yang dialami tersebut. Dengan adanya permasalahan tersebut maka diperlukan sebuah sistem informasi akuntansi dan desain sistem untuk perputaran upah yang efisien dan efektif, disebabkan sistem ini sangat berpengaruh besar bagi perusahan memenuhi kebutuhan pihak eksternal dan pihak menajemen.

Terdapat penelitian terdahulu yang membahas tentang Sistem Informasi Akuntansi Penggajian. Hasil penelitian yang dilakukan Suginam (2017) menunjukkan bahwa PT. Yuki Abadi Medan masih menggunakan program lotus untuk penggajiannya, sehingga penginputan perhitungan gaji membutuhkan waktu yang lama. Hasil penelitian yang dilakukan oleh Gunawan (2012) pada PT. BO ini ditemukan permasalahna yang mana perusahaan sulit memperhitungkan gaji para lkaryawannya disebabkan tidak adany atolak ukur pada perusahaan PT. BO serta tidak adanya perkas penyimpanan yang dibuat agar gaji karyawan menjadi benar-benar valid pada sebuah sistem dan tersimpan. Sebuah penelitian menunjukan bahwa sebuah pengukuran dari setiap upah perusahaan kepada karyawan akan bisa lebih cepat terdeteksi dengan baik jika dibuatnya sistem secara komputerisasi.

Seperti penelitian terdahulu, penelitian ini juga akan meneliti perancangan sistem informasi akuntansi penggajian dengan objek penelitian pada CV. Serampang Jaya yang terletak di Jl. Maskuning Kulon Kecamatan Pujer Bondowoso. CV. Serampang Jaya bergerak di bidang penggilingan, produksi dan penjualan beras berkualitas. Berdasarkan observasi terhadap sistem penggajian pada $\mathrm{CV}$. Serampang Jaya ditemukan permasalahan yaitu banyaknya golongan karyawan kurang lebih 100 orang karyawan, sehingga perhitungan gaji membutuhkan waktu relatif lama (kurang lebih 4 hari) dan 
perhitungannya dilakukan secara manual dan hanya dilakukan oleh seorang karyawan. Selain itu tanggal penggajian yang berbeda antara karyawan dengan buruh yang dilakukan secara manual, maka pelaporan total pembayaran gaji bulanan terhambat seperti terlihat pada gambar 1.1 dibawah saat ini CV. Serampang Jaya tidak memiliki dokumen pendukung yang memadai presensi dan rekapitulasi gaji pegawai menjadi satu bagian dan dilakukan oleh seorang bendahara saja oleh sebab itu maka bagian penggajian harus mengumpulkan data pembayaran gaji karyawan terlebih dahulu. Dengan banyaknya karyawan CV. Serampang Jaya seharusnya menggunakan sistem informasi akuntansi penggajian yang memadai untuk mempermudah bagian keuangan melakukan penggajian pada karyawan serta meningkatkan kualitas informasi yang dibutuhkan perusahaan.

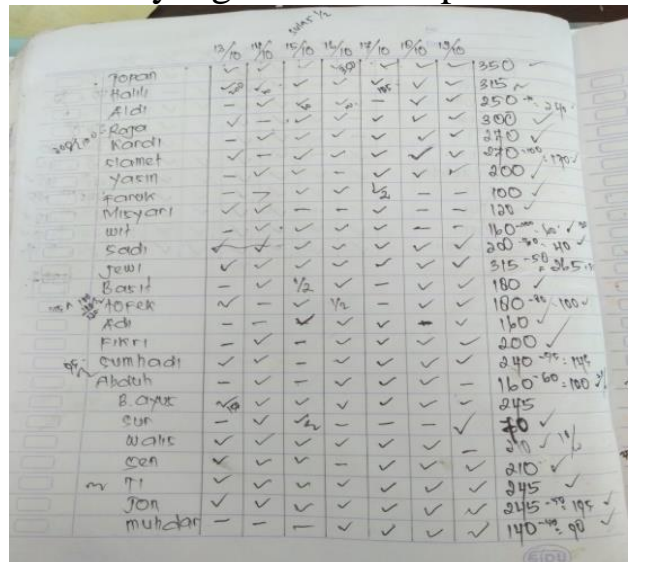

Gambar 1 Absensi karyawan Sumber CV Serampang Jaya

Keutamaan dari sebuah sistem akuntasi penggajian ialah meminimalisirkan sebuah kesalahan yang akan mengakibatkan ketidak validan data serta memungkinkan untuk kebenaran dari data yang dicantumkan pada sebuah perusahaan tersebut (Mulyadi 2001) dapat ketika ketahui bahwa sebuah sistem akuntansi yang baik dan sesuai prosedur akan tercipta jika dalam sebuah perusahaan tersebut menerapkan sistem akuntansi yang baik dan harus adanya pelatihan dan penerapan secara nyat.maka dapat diketahui bahwa sistem akuntansi penggajian sangat penting bagi $\mathrm{CV}$. Serampang Jaya untuk diperhatikan.

Menurut Romney, dkk (2006) sistem adalah sebuah susunan dari dua atau lebih komponen-komponen yang saling berhubungan, yang berhubungan untuk mencapai suatu tujuan. Sistem hampir terdiri dari beberapa subsistem kecil, yang masing-masing melakukan fungsi khusus yang penting untuk dan mendukung bagi sistem yang lebih besar, tempat mereka berada.

Menurut Susanto (2004) definisi sistem sebagai berikut: Sistem adalah kumpulan atau group dari sub sistem atau bagian atau komponen apapun baik phisik maupun non phisik yang saling berhubungan satu sama lain dan bekerja sama secara harmonis untuk mencapai suatu tujuan tertentu.

Menurut Widjajanto (2001) sistem adalah dua atau lebih komponen yang bekerja sama sebagai keseluruhan yang diorganisasikan dengan batas yang dapat diidentifikasi.

Jadi definisi sistem secara umum adalah suatu paduan yang terdiri dari beberapa unsur yang tergabung satu sama lain agar mempermudah laju aliran informasi, energi ataupun materi hingga mencapai tujuan tertentu yang sudah ditetapkan.

Menurut Mulyadi (2001) sistem informasi akuntansi adalah sebuah formulir, catatan, dan laporan yang disususn sedemikian rupa untuk menyediakan informasi keuangan yang dibutuhkan oleh manajemen guna memudahkan pengelolaan perusahaan.

Sedangkan menurut Widjajanto (2001) Sistem informasi akuntansi adalah susunan berbagai formulir catatan, peralatan, termasuk komputer 
dan perlengkapannya serta alat komunikasi, tenaga pelaksananya, dan laporan yang terkoordinasikan secara erat yang didesain untuk menghubungkan data keuangan menjadi informasi yang dibutuhkan manajemen.

Jadi bisa disimpulkan sistem informasi akuntansi merupakan suatu sistem informasi yang dibuat khusus untuk memudahkan kegiatan dan segala sesuatu yang berhubungan dengan akuntansi, yang meliputi suatu komponen dokumen, mengklasifikasikan, mengolah, menganalisa dan menghubungkan informasi finansial dan pengambilan keputusan yang relevan bagi pihak perusahaan dan pihak ekstern.

Sistem Penggajian menurut Jogiyanto (2005) sistem penggajian sangat bervariasi, antara lain Sistem penggajian tetap Sistem penggajian tetap adalah dimana pegawai dalam sistem ini akan mendapatkan gaji yang besarnya relatif tetap, misalnya seorang pegawai lembur, pegawai tersebut tidak mendapat uang lembur dan sebaliknya apabila pegawaii tersebut absen atau tidak masuk maka gaji pegawai tersebut dikurangi.

Komponen-komponen gaji tetap 1) gaji pokok Gaji pokok adalah gaji yang dibayar sesuai dengan standard yang telah ditentukan oleh Departemen Tenaga Kerja, 2) tunjangan Tunjangan adalah imbalan yang diberikan atau disediakan oleh perusahaan baik berupa uang maupun berupa Natura (pendapatan) yang bersifat tidak tetap, 3) lembur adalah jam kerja melebihi 7 (tujuh) jam sehari atau melebihi 40 (empat puluh) jam dalam seminggu, 4) potongan adalah segala macam bentuk pengurangan-pengurangan dalam penggajian yang telah ditentukan oleh perusahaan. Selain itu terdapat sistem penggajian variabel pada sistem penggajian ini pegawai mendapatkan operasional dengan persentasi. Sedangkan pada sistem penggajian tetap dan variabel pegawai mendapat gaji tertentu, tetapi bila pegawai tersebut lembur atau melakukan prestasi tertentu akan mendapatkan uang tambahan, sebaliknya bila tidak masuk kerja atau terlambat masuk kerja maka gajinya akan di potong. Berdasarkan uraian beberapa ahli tentang teori sistem informasi akuntansi penggajian penulis dapat merancang kerangka konseptual seperti gabar berikut berikut.

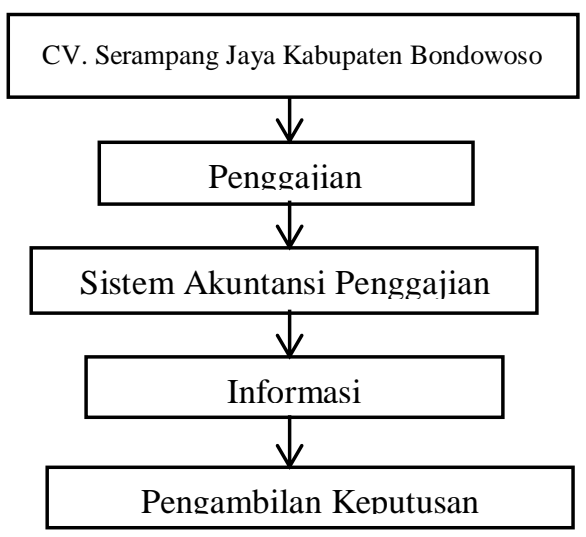

Gambar 1. Kerangka Pemikir

\section{METODE PENELITIAN}

Penelitian ini bertujuan untuk memberikan gambaran mengenai sistem penggajian dan pengupahan pada $\mathrm{CV}$. Serampang Jaya Bondowoso. Metode penelitian ini menggunakan metode deskriptif kualitatif, dimana penelitian ini dilakukan dengan cara mengumpulkan data menganalisis, meneliti dan merancang sistem informasi akuntansi penggajian pada CV. Serampang Jaya Kabupaten Bondowoso.

Data yang dikumpulkan oleh peneliti dalam rangka memperoleh data yang diperlukan, maka peneliti menggunkanan dua sumber data yaitu : Data Primer dan Data sekunder. Teknik Pengumpulan Data yang digunakan dalam penelitian ini yaitu: Teknik 
Dokumentasi, Teknik wawancara dan Teknik pengamatan/observasi.

Teknik analisis data yang digunakan untuk memecahkan permasalahan adalah dengan cara menganalisis data-data penelitian yaitu dokumen yang berkaitan dengan sistem penggajian apakah sistem yang berjalan sudah memadai atau belum serta memberikan rekomendasi rancangan sistem informasi akuntansi yang memadai.

Bodnar dan William (1995), langkah - langkah tahap rancangan sistem sebagai berikut: 1) evaluasi alternatif-alternatif rancangan, 2) pembuatan spesifikasi-spesifikasi rancangan, 3) pembuatan dan penyampaian spesifikasi rancangan sistem. Langkah-langkah yang akan dilakukan sebagai berikut: 1) merancang struktur organisasi yang memisahkan tanggung jawab fungsional secara tegas beserta tugas dan wewenangnya, 2) merancang sistem akuntansi penggajian dengan membuat: a) prosedur sistem akuntansi penggajian, b) flowchart, 3) merancang formulir/Dokumen yang dapat memenuhi kebutuhan pengguna atau pihak manajemen.

\section{HASIL DAN PEMBAHASAN \\ Sistem Informasi Akuntansi Penggajian}

1. Prosedur pencataan kehadiran pegawai

Prosedur pencatatan waktu hadir pegawai atau juga disebut sebagai presensi, bertujuan untuk mencatat waktu kehadiran pegawai, pencatatan waktu hadir ini dibuat oleh bagian bendahara. Masingmasing bagian mengisi daftar hadir yang sudah dibuat, yang selanjutnya akan didistribusikan ke bagian bendahara untuk kepentinagn pegawai pada masingmasing bagian.

2. Prosedur pembuatan daftar rekapitulasi gaji pegawai

Prosedur pembuatan daftar rekapitulasi gaji dan upah dilaksanakan oleh bagian bendahara. Bagian ini bertugas untuk daftar rekapitulasi gaji pegawai berdasarkan daftar skala gaji.

Dari Gambar 1 sebelumnya dapat dilihat pada gambar diatas bahwa absensi dan rekapitulasi gaji pegawai tercampur menjadi satu, seharusnya ada pemisahaan tersendiri antara presensi pegawai dengan rekapitulasi gaji pegawai agar dapat diketahui dengan jelas tugas-tugas perbagian pegawai.

\section{Bagan Alir Flowchart}

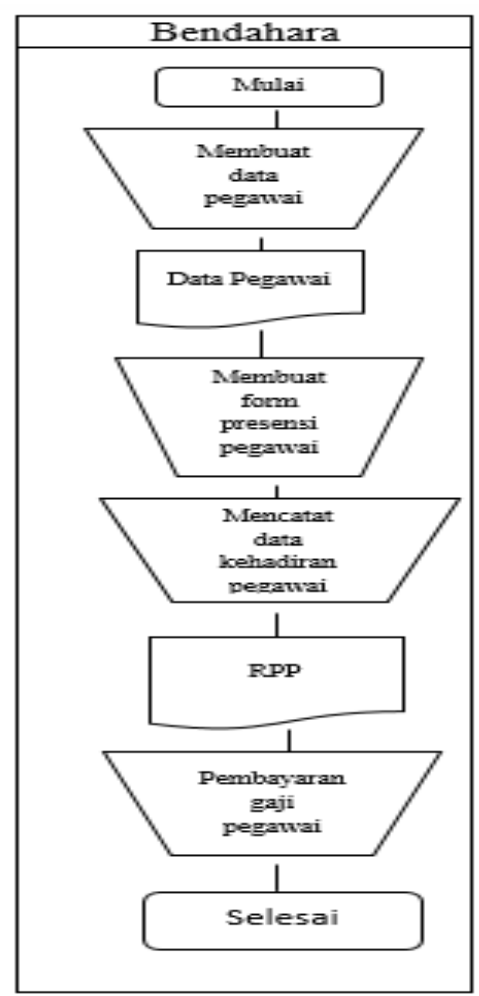

Gambar 2 Bagan Alir Flowchart 
Rancangan Sistem Informasi

\section{Akuntansi Penggajian}

1. Prosedur Sistem

\section{Penggajian.}

a. Prosedur membuat daftar hadir pegawai

Prosedur pembuatan daftar hadir pegawai digunakan untuk merekam data kehadiran (presensi) pegawai setiap hari.

b. Catatan waktu kerja

Catatan waktu kerja dapat dikumpulkan oleh petugasnya dari buku catatan mandor dan daftar hadir.

c. Prosedur membuat kombinasi catatan hadir dan waktu kerja Kartu ini diperuntukkan kepada karyawan digunakan oleh fungsi pencatat waktu untuk mencatat jam hadir setiap karyawan untuk menegrjakan job pada hari itu dan juga disediakan kolom untuk mencatat jam datang dan jam pulang.

d. Prosedur membuat daftar gaji Prosedur pembuatan gaji terdiri dari proses: membuat daftar gaji dan ringkasan gaji pegawai. Data yang dipakai adalah data pegawai, surat keputusan pengangkatan pegawai dan ringkasan presensi.

e. Prosedur membuat ringkasan presensi pegawai

Rancangan ringkasan presensi pegawai adalah rancangan format tabel untuk meringkas data-data presensi pegawai dalam CV. Serampang Jaya. Ringkasan presensi pegawai dibuat oleh koordinator presensi dan didistribusikan kepada koordinator gaji sebagai pertibangan apakah pegawai yang tercantum dalam ringkasan tersebut meperoleh penanbahan atau pengurangan gaji dilihat dari jumlah hadir atau tidaknya pegawai di kantor kecuali dengan alasan yang jelas.

f. Prosedur perancangan ringkasan gaji pegawai

Rancangan ringkasan gaji pegawai adalah rancangan forat tabel untuk meringkas data-data gaji pegawai dalam CV.Serampang Jaya selama satu bulan. Ringkasan ini digunakan sebagai dasar dalam membuat laporan total gaji perbulan. Ringkasan gaji pegawai dibuat oleh koordinator gaji dan diserahkan kepada bagian keuangan.

g. Prosedur perancangan slip gaji pegawai

Rancangan slip gaji pegawwai adalah rancangan bukti informasi resi penerimaan gaji dari pemberi kerja kepada pegawai yang akan diterima dengan ditandatangani langsung oleh seorang HRD perusahaan.

h. Prosedur perancangan bukti pengambilan gaji

Rancngan bukti pengambilan gaji adalah rancangan format tabel yang digunakan untuk mencatat data dan pengambilan gaji oleh tiap pegawai.

2. Rekomendasi Bagan Alir Flowchart Sistem Informasi Akuntansi Penggajain.

a. Fungsi-fungsi yang terkait. Fungsi-fungsi yang terkait dalam rancangan proses akuntansi penggajian difokuskan pada fungsi yang bertugas untuk elakukan tugasnya sesuai bagiannya. 
b. Bagian Presensi. Bagian Presensi bertugas untuk membuat presensi pegawai dan juga bertugas untuk membuat ringkasan presensi pegawai guna untuk diserahkan kepada bagian koordinator gaji.

c. Bagian Koordinator Gaji. Bagian koordinator gaji bertugas untuk menghitung gaji pegawai, merekap gaji pegawai dan membuat slip gaji pegawai.

d. Bagian Koordinator Pembayaran Gaji. bertugas untuk membuat bukti pengambilan gaji, memberikan slip gaji kepada pegawai pada saat pebayaran gaji, dan membuat laporan bukti bahwa gaji sudah diambil oleh pegawai yang bersangkutan.

\section{Flowchart}

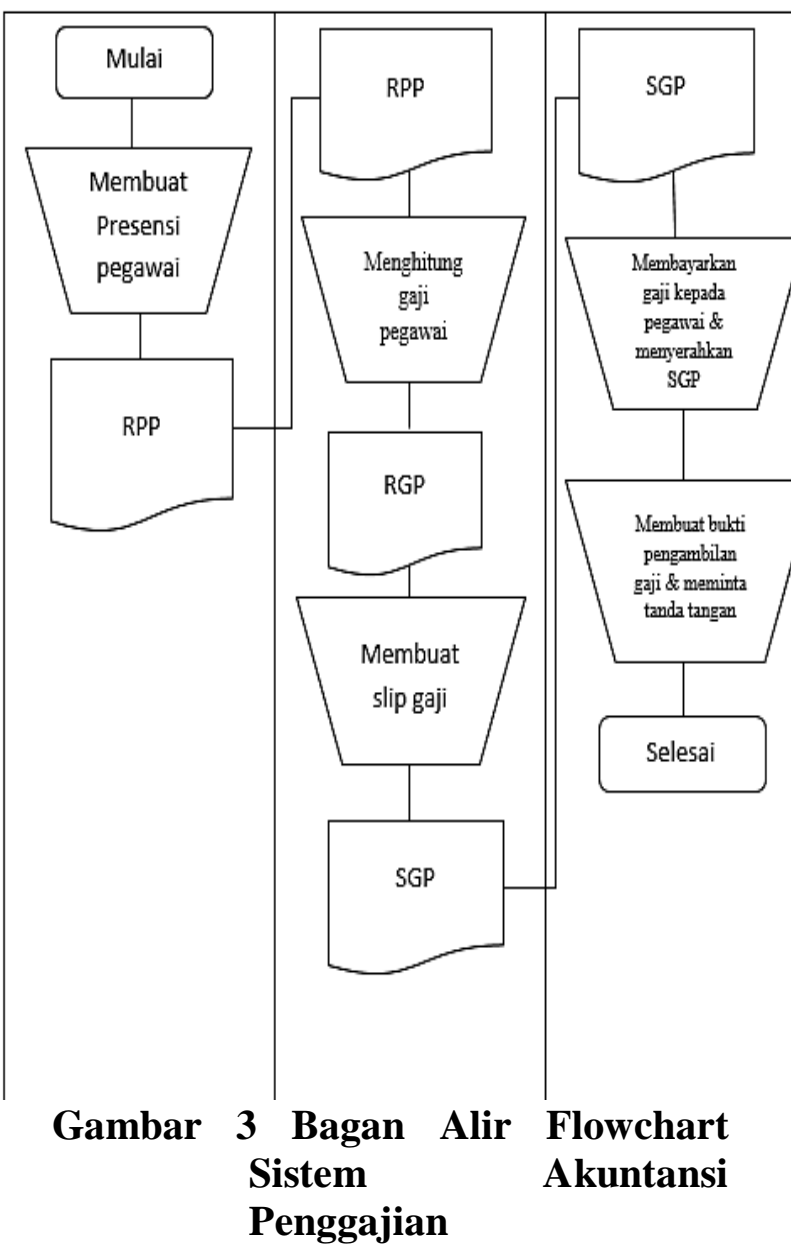

4. Merancang formulir/dokumen sistem informasi akuntansi penggajian.

a. Pencatatan waktu hadir pegawai (presensi)

Rancangan tabel presensi pegawai adalah tampilan tabel yang digunakan untuk merekam data kehadiran (presensi) pegawai setiap hari. Data-data yang direkam menggunakan tabel presensi pegawai diantaranya; nama bagian, tanggal/bulan/tahun kehadiran, nama pegawai, keterangan presensi. Rancangan tabel presensi pegawai dapat dilihat pada tabel berikut ini:

\section{Tabel 1.}

\section{Presensi Karyawan}

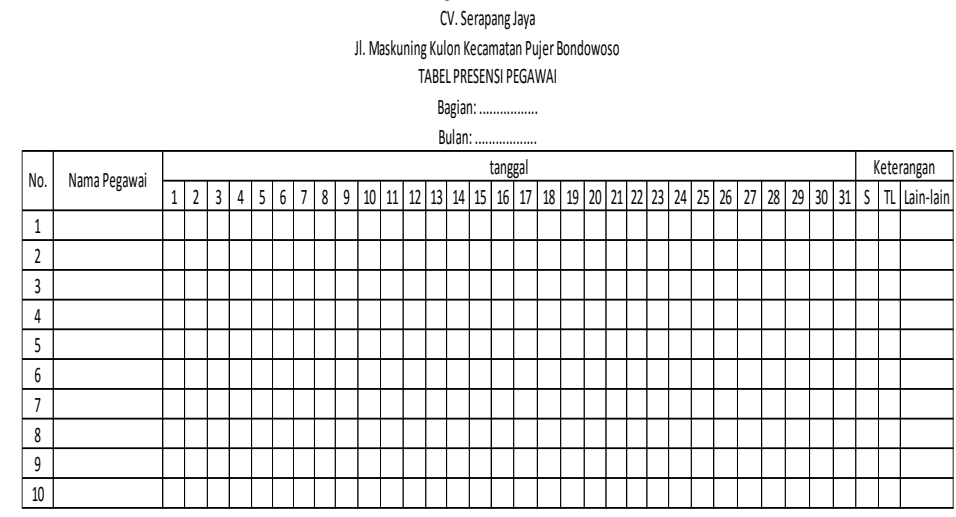

b. Catatan waktu kerja. Catatan waktu kerja dapat di kumpulkan oleh petugasnya dari buku catatan mandor dan daftar hadir.

c. Kombinasi Catatan Waktu Hadir dan Waktu Kerja. Kartu ini digunakan kepada karyawan fungsi pencatat waktu untuk memudahkan mencatat jam hadir setiap karyawan dan untuk menegrjakan pekerjaan pada hari itu dan juga disediakan kolom sebagai untuk mencatat jam datang dan jam pulang. 
Tabel 2 Kombinasi Catatan Waktu

Hadir dan Waktu Kerja

\begin{tabular}{|c|c|c|c|c|c|c|}
\hline \multirow[t]{2}{*}{ No. } & \multicolumn{2}{|l|}{ Nama: } & & & \multicolumn{2}{|l|}{ Bulan: } \\
\hline & \multicolumn{2}{|c|}{ Bagian: } & & & \multicolumn{2}{|l|}{ Tahun: } \\
\hline \multirow{2}{*}{ TGL } & \multicolumn{2}{|c|}{ PAGI } & \multicolumn{2}{|c|}{ SIANG } & \multicolumn{2}{|c|}{ LEMBUR } \\
\hline & Masuk & Keluar & Masuk & Keluar & Masuk & Keluar \\
\hline 1 & & & & & & \\
\hline 2 & & & & & & \\
\hline 3 & & & & & & \\
\hline 4 & & & & & & \\
\hline 5 & & & & & & \\
\hline
\end{tabular}

d. Daftar Gaji. Daftar gaji merupakan daftar yang menunjukkan perhitungan gaji dan upah masing-masing karyawan selama periode tertentu. Daftar gaji ini merupakan buku jurnal gaji. Dalam daftar gaji setiap baris digunakaan untuk satu karyawan, menunjukkan nomor, nama, tarif upah dan gaji, jumlah gaji biasa dan lembur, tunjangan-tunjangan, ptonganpotongan dan jumlah gaji bersih.

\section{Tabel 3 Daftar Gaji}

Daftar Gaji Pegawai CV. SERAMPANG JAYA

\begin{tabular}{|c|c|c|c|c|c|c|}
\hline No. & Nama & Jabatan & $\begin{array}{c}\text { Gaji } \\
\text { Pokok }\end{array}$ & Status & Tunjangan & $\begin{array}{c}\text { Jml. } \\
\text { Gaji }\end{array}$ \\
\hline 1 & & & & & & \\
\hline 2 & & & & & & \\
\hline 3 & & & & & & \\
\hline 4 & & & & & & \\
\hline 5 & & & & & & \\
\hline
\end{tabular}

e. Amplop gaji. Amplop gaji harus menunjukkan nama karyawan dan jumlah gaj

f. Rancangan Ringkasan Presensi Pegawai Rancangan ringkasan presensi pegawai adalah rancangan format tabel untuk meringkas data-data presensi pegawai dalam CV. Serampang Jaya. Ringkasan presensi pegawai berisi informasi, nama bagian, bulan presensi, nama pegawai dan jumlah total hadir tidak hadir pegawai. Ringkasan presensi pegawai dibuat oleh koordinator presensi dan didistribusikan kepada koordinator gaji sebagai pertibangan apakah pegawai yang tercantum dalam ringkasan tersebut meperoleh penanbahan atau pengurangan gaji dilihat dari jumlah hadir atau tidaknya pegawai di kantor kecuali dengan alasan yang jelas.

\section{Tabel 4 Ringkasan Presensi Pegawai}

CV. SERAMPANG JAYA

Jl. Maskuning Kulon Kecamatan Pujer Bondowoso

RINGKASAN PRESENSI PEGAWAI

Bagian:.

\begin{tabular}{|r|l|l|l|l|l|}
\hline \multirow{2}{*}{ No. } & \multirow{2}{*}{ Nama } & \multirow{4}{*}{ Hadir } & \multicolumn{4}{|c|}{ Tidak hadir } \\
\cline { 4 - 6 } & & & S & TL & TB \\
\hline 1 & & & & & \\
\hline 2 & & & & & \\
\hline 3 & & & & & \\
\hline 4 & & & & & \\
\hline 5 & & & & & \\
\hline
\end{tabular}

g. Rancangan ringkasan gaji pegawai. Rancangan ringkasan gaji pegawai adalah rancangan forat tabel untuk meringkas data-data gaji pegawai dalam CV. Serampang jaya selama satu bulan. Ringkasan ini digunakan sebagai dasar dalam membuat laporan total gaji perbulan, ringkasan gaji pegawai berisi informasi nama 
bagian, bulan, jumlah pegawai perbagian, dan perincian gaji, tunjangan dan potongan. Ringkasan gaji pegawai dibuat oleh koordinator gaji dan diserahkan kepala bagaian keuangan.

\section{Tabel 5. Ringkasan gaji pegawai}

CV. Serampang Jaya

Jl. Maskuning Kulon Kecamatan Pujer Bondowoso

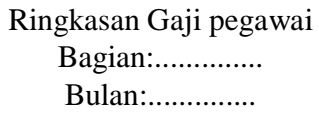

\begin{tabular}{|c|c|c|c|c|c|}
\hline No. & Keterangan & $\begin{array}{c}\text { Bagian } \\
1 \\
\end{array}$ & $\begin{array}{c}\text { Bagian } \\
2 \\
\end{array}$ & $\begin{array}{c}\text { Bagian } \\
3 \\
\end{array}$ & $\mathrm{Jlh}$ \\
\hline 1 & $\begin{array}{l}\text { Jumlah } \\
\text { pegawai }\end{array}$ & & & & \\
\hline 2 & Gaji Pokok & & & & \\
\hline 3 & Potongan & & & & \\
\hline & $\begin{array}{l}\text { Hutang lain- } \\
\text { lain }\end{array}$ & & & & \\
\hline & $\begin{array}{l}\text { Jumlah } \\
\text { potongan }\end{array}$ & & & & \\
\hline 4 & Jumlah & & & & \\
\hline & $\begin{array}{l}\text { Penghasilan } \\
\text { bersih }\end{array}$ & & & & \\
\hline
\end{tabular}

h. Rancangan slip gaji pegawai Rancangan slip gaji pegawai adalah rancangan bukti informasi resi penerimaan gaji dari pemberi kerja kepada pegawai. Slip gaji berisi informasi diantaranya yaitu, tanggal, nama, bagian, tunjangan, gaji pokok, potongan lembur dan jumlah gaji yang akan diterima dengan ditandatangani langsung oleh seorang HRD perusahaan.

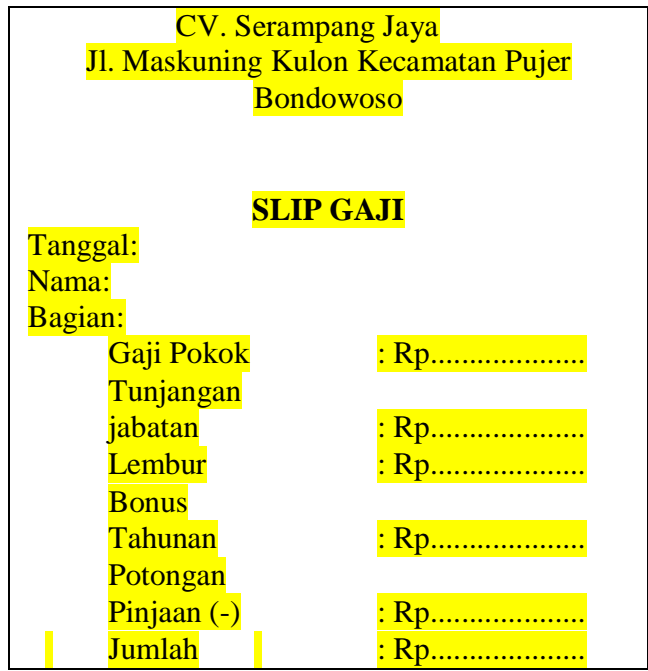

\section{Gambar 3 Slip Gaji Pegawai}

i. Rancangan bukti pengambilan gaji. Rancangan bukti pengambilan gaji adalah rancangan format tabel yang digunakan untuk mencatat data dan pengambilan gaji oleh tiap pegawai. Bukti pengambilan gaji berisi informasi menegenai nama bagian, bulan, nama pegawai, dan tanda tangan pegawai. Bukti pengambilan gaji dibuat oleh koordinator pebayaran gaji berdasarkan slip gaji pegawai.

\section{Tabel 6 Bukti Pengambilan Gaji}

CV. Serampang Jaya

Jl. Maskuning Kulon Kecamatan Pujer Bondowoso

Bukti Pengambilan Gaji

Bagian: .................
\begin{tabular}{|c|c|c|} 
Bulan: .................. & Nama Pegawai & Tandatangan \\
\hline No. & & \\
\hline 1 & & \\
\hline 2 & & \\
\hline 3 & & \\
\hline 4 & & \\
\hline 5 & & \\
\hline 6 & & \\
\hline 7 & & \\
\hline 8 & & \\
\hline 9 & & \\
\hline 10 & & \\
\hline
\end{tabular}




\section{PENUTUP}

\section{Kesimpulan}

Berdasarakan analisis dan perancangan sistem akuntansi penggajian yang telah dilakukan, maka dapat diambil kesimpulan sebagai berikut:

1. CV. Serampang jaya sudah menggunakan sistem akuntansi penggajian, tetapi masih sederhana. Sistem yang saat ini digunakan masih memerlukan pengembanganpengembangan untuk meningkatkan efektivitas kegiatan penggajian. Kelemahan yang terdapat dalam sistem ini yaitu belum adanya pemisahan tugas didalam bagian kepegawaian dan bagian keuangan, pembuatan dokumen berupa data pegawai dan daftar hadir pegawai masih sederhana dan belum sesuai dengan sistem informasi akuntansi penggajian, pengarsipan dokumen belum tertata rapi dan rentan terhadap kerusakan dokumen, fungsi yang terkait dalam proses penggajian belum terorganisir dan belum terpisah tanggung jawabnya, sehingga terdapat jabatan rangkap dalam setiap bagian, CV. Serampang jaya tidak mepunyai skema yang menjelaskan mengenai arus proses sistem penggajian (flowchart dan diagram arus data) dan tidak ada ringkasan presensi pegawai

2. Rancangan sistem akuntansi penggajian ini dibuat berdasarkan kelemahan atau pun permasalah yang ter identifikasi dalam CV. Serampang Jaya, yaitu belum ada pemisahan tugas dan tanggung jawab didalam bagian kepegawaian (koordinator presensi dan koordinator pembinaan karyawan) dan bagian keuangan (koordinator gaji, koordinator akuntansi dan koordinator pebayaran gaji) serta fungsi pemegang kas sebagai pembuat bukti kas keluar dan slip gaji perlu pengawasan yang lebih. Rancangan sistem akuntansi penggajian dibuat sederhana mungkin agar bisa dimengerti dan diharapkan dapat membantu mengorganisasikan kegiatan dalam CV. Serapang Jaya.

\section{Saran}

Dari hasil penelitian terhadap sistem akuntansi penggajian terdapat beberapa saran bagi CV. Serampang Jaya untuk membantu dalam pelaksaan kegiatan penggajian anatara lain:

1. Sebaiknya menggunakan presensi pegawai yang dipisah antara presensii dengan rekap gaji pegawai.

2. Sebaiknya menggunakan catatan waktu hadir dan waktu kerja guna untuk mencatat jam hadir setiap karyawan untuk mengerjakan pekerjaan pada hari itu. Dengan demikian catatan waktu kerja ini dipakai sebagai dasar pebebanan gaji atas apa yang telah karyawan selesai kerjakan.

3. Sebaiknya menggunakan daftar gaji guna untuk mengetahui gaji per masing-masing bagian.

4. Sebaiknya menggunakan ringkasan prsesensi pegawai guna untuk memepertibangkan apakah pegawai yang tercantum dalam ringkasan tersebut memperoleh penambahan atau pengurangan gaji dilihat dari jumlah hadir atau tidaknya pegawai di kantor kecuali dengan alasan yang jelas.

5. Sebaiknya menggunakan ringkasan gaji pegawai sebagai dasar dalam mebuat laporan total gaji perbulan.

6. Sebaiknya menggunakan slip gaji pegawai sebagai bukti inforasi resi penerimaan gaji dari pemberi kerja kepada pegawai. 
7. Sebaiknya menggunakan bukti pengambilan gaji guna untuk mengetahui pegawai yang telah menerima gaji.

\section{DAFTAR PUSTAKA}

Bodnar, G., H \& William S. H. (1995). Sistem Informasi Akuntansi. Jakarta: Salemba Empat

Gunawan, R. (2012). Perancangan Sistem Komputerisasi Penggajian dan Pengupahan pada Perusahaan Percetakan. Berkala Ilmiah Mahasiswa Akuntansi, 1(1).

Jogiyanto. (2005). Analisis dan Desain Sistem Informasi. Yogyakarta:Andi.

Mulyadi, (2001). Sistem Akuntansi. Edisi ketiga, Cetakan Ketiga, Jakarta. Salemba Empat.

Romney B.,M \& Steinbart, P., J. (2006). Sistem Informasi Akuntansi, Edisi Sembilan, Buku Satu, diterjemahkan: Deny Arnos Kwary dan Dewi Fitriasari. Jakarta: Salemba Empat

Susanto, A. (2004). Sistem Informasi Akuntansi. Bandung: Lingga Jaya

Suginam, S., Nasution, S. D., Aripin, S., \& Fau, A. (2017). Perancangan Sistem Informasi Akuntansi Penggajian Karyawan. Pelita Informatika: Informasi dan Informatika, 16(3).

Widjajanto, N. (2001). Sistem Informasi Akuntansi. Jakarta: Erlangga 